\title{
STUDENTS' RESPONSES TOWARD THE IMPLEMENTATION OF BINGO GAME WITH SCIENTIFIC APPROACH IN TEACHING WRITING DESCRIPTIVE TEXT
}

\author{
Febriani Sahnaputri ${ }^{1}$, Evie Kareviati ${ }^{2}$ \\ 1,2 IKIP Siliwangi \\ ${ }^{1}$ febrianisputri@ student.ikipsiliwangi.ac.id, ${ }^{2}$ ekareviati@gmail.com
}

\begin{abstract}
This study aimed to investigate the implementation of the Bingo game technique in teaching writing and to find out the students' participation toward the implementation of the Bingo game. The research instruments used interview and observation sheet. This study was conducted at Junior High School in Cimahi. The students of VII F class were selected as the participant of the research. The research used descriptive qualitative method. The data was obtained from classroom observation and students' interview. The result showed that Bingo game can be used to motivate students in writing skill. It was very helpful in providing the students with more enjoyable activities which made the students involved in the teaching and learning process actively.
\end{abstract}

Keywords: Writing, Bingo Game, Descriptive Text

\section{INTRODUCTION}

Writing is one of four skills such as speaking, reading, and listening that students must master. According to Blanchard and Root (1998: 1) as cited in Yulianti, Nuraeni, \& Parmawati, (2019) "learning to write in a new language is not always easy". Brown (2004: 255) as cited in Yulianti, Nuraeni, \& Parmawati, (2019) state that "Writing is a process to create some ideas of students' knowledge to be a written". This statement in line with Gebhard (1996) cited in Farizi \& Fauzyah (2019) state that writing has several parts that must be considered including word choice, use of appropriate grammar, syntax, mechanism, organization of ideas into coherent and cohesive. Elements of writing are vocabulary, function, grammar, and spelling, especially in writing descriptive text.

Language, Science, \& Maumere (2018) as cited in Hanafiawi, Muharam, \& Parmawati (2020) state that descriptive text is one of the genres of the text. Descriptive text that describes people, animals, or things. Descriptive text is to describe what we see. A good description is usually logically written and clear details. Furthermore, Abisamra (2001:1) as cited in (Jayanti, 2019) state that "descriptive is the text picturing the person, place, and thing with clear detail to help the readers visualize an object which is described". It means that writing a descripvite text is activity to describe an object clearly and readers can easily to be understood.

Bingo game is an incredibly fun and easy game to play whether in the group or individual. According to Coco, et.al (2001) as cited in Noviyanti, Bahri \& Chairina (2019) Bingo game can be called a holistic game, because can make the player feel enjoy the game. Also, this game can be used to teach English. 
Finch (2006) as cited in Noviyanti, Bahri \& Chairina (2019) state that Bingo game have several types that used as follow:

a. Picture Bingo (picture to picture, picture to word)

In this type, the teacher uses a picture to play the game. The teacher shows the picture in front of the class and asks the students to guess what the picture means.

The students should say one word based on the picture.

b. Word Bingo (word to picture, word to word)

In this type, the teacher uses a sentence to describe the word. The teacher will give a clue for students by using word. Then, the teacher asks the students to find the word that the teacher means.

c. Synonim Bingo (similar word)

The teacher uses the synonym word when she/he gives the clue to the students. The students should find the word that has similar meaning with the word that the teacher says.

d. Antonym Bingo (opposite word)

The teacher uses the antonym word when she/he gives the clue to the students. The students should find the word that has the opposite meaning with the word that the teacher says.

e. Translation Bingo (Indonesia-English, English-Indonesia)

In this type, the teacher gives a clue with translation word (Indonesian word).

Then, the students should find the meaning (English word).

f. Matching Bingo (matching a sportsperson to a sport, a singer to a song, etc)

The teacher uses some picture to give a clue for the students. The teacher asks the students to match the picture with another picture.

g. 20 Questions Bingo (asking questions about the words)

The teacher gives students 20 close questions that each of questions gives a clue for the answer. The students just answer the question by circle "yes" or "no", it is depend on their answer.

h. Riddle Bingo (definitions-dictionary)

The teacher gives the students the definition of word as a clue. Then, the teacher asks the students to find the word that related to the definition of the word that the teacher says.

i. Pyramid Bingo (using a different format for the Bingo card)

As we know that, the format of Bingo card is table which consist some rows and column. Usually to get the Bingo we should to get the straight horizontal or straight vertical pattern. But, in this type, the teacher uses other patterns of Bingo card, such as pyramid, tree, airplane pattern, etc.

j. Idiom Bingo (explanations)

In this type, the teacher gives students the meaning of one idiom as a clue. The teacher asks the students to find the suitable idiom that has related to the meaning that the teacher gives. And the researcher used translation Bingo for teaching learning process. In the translation bingo the students will be translating the words in Indonesian to English.

\section{METHOD}

This design of this research was a descriptive qualitative method. Sugiyono (2005) as cited Ernawati, Purnomo, \& Suryani (2019) state that descriptive research describe the results of the 
study but not be used to make broader conclusions. This study was conducted in SMPN 5 Cimahi with the participant of the study was the students of VII F which consist of 34 students. The data of the study were collected from interview and observation. The observation was used to obtain information based on the implementation of Bingo game during the learning process in the class. Marshall \& Rossman (1998:79) as cited in Nurmalasari \& Apsari (2019) state that the systematic description of events, behaviors, and artifacts in the social setting chosen for study The observation was used to get the information and respond students regarding the implementation of bingo game technique during the lesson. The English teacher was being involved in the process. She helped the researcher to observe the activity from both the researcher and students during the learning process in the classroom. Furthermore, Kvale (1996:174) as cited Nurmalasari \& Apsari (2019) explain that interview is "a conversation, whose purpose is to gather descriptions of the life-world of the interviewee" concerning the interpretation of the meanings of the 'described phenomena'. The interview was conducted with 4 students of VII F class, they are the students with different levels of participation in the class.

\section{RESULTS AND DISCUSSION}

\section{Results}

The interview was conducted at the end of the implementation of Bingo game. The interview was consist of 6 questions, the interview is as follow:

\begin{tabular}{lll}
\hline No & Question & Students' Responses \\
\hline 1 & $\begin{array}{l}\text { In the English lesson, there are four skills, } \\
\text { which is listening, speaking, reading, and } \\
\text { writing. Of the four skill components, } \\
\text { which one do you like most? }\end{array}$ & $\begin{array}{l}\text { Twe difficult, and two of them like reading } \\
\text { because it just need read a book. }\end{array}$ \\
\hline 2 & $\begin{array}{l}\text { From the four skills previously mentioned, } \\
\text { which do you think is the most difficult? } \\
\text { why? }\end{array}$ & $\begin{array}{l}\text { Three of them state that grammar the most } \\
\text { difficult because grammar rules are tricky } \\
\text { one of the biggest reasons that learning } \\
\text { and using grammar correctly is so difficult } \\
\text { is that there are so many exceptions to } \\
\text { every rule. One of them states that }\end{array}$ \\
& $\begin{array}{l}\text { listening is the most difficult because the } \\
\text { sound is heard same but the meaning is } \\
\text { different. }\end{array}$ \\
\hline 3 & $\begin{array}{l}\text { Do you like learning writing using Bingo } \\
\text { game? }\end{array}$ & $\begin{array}{l}\text { Most respondents said that they like } \\
\text { learning writing using Bingo game } \\
\text { because it was fun and got a lot of new } \\
\text { vocabulary. }\end{array}$ \\
\hline $\begin{array}{l}\text { Does playing Bingo game make you } \\
\text { motivated in learning writing? }\end{array}$ & $\begin{array}{l}\text { Most of them state that Bingo game } \\
\text { motivated them to learn writing. The } \\
\text { learning process became fun and made the } \\
\text { students interesting to learn writing. One } \\
\text { student said that he do not like English } \\
\text { because boring but after playing Bingo } \\
\text { game, he started to like it. }\end{array}$ \\
\hline $\begin{array}{l}\text { What progress have you felt during } \\
\text { teaching learning activities using Bingo } \\
\text { game? }\end{array}$ & $\begin{array}{l}\text { All of the students stated that progress } \\
\text { during learning using Bingo game is got a } \\
\text { lot of new vocabularies. }\end{array}$ \\
\hline
\end{tabular}



understand because it help them in adding vocabulary. When they knew the new vocabulary, it will be able to write better.

\section{Discussion}

From the data interview, all respondents said that Bingo game can help them to get a lot of new vocabulary. Bingo game is one effective method to make students easy to remember new words. The students told that Bingo game was fun and made them enjoy the learning process. In the first meeting, most of the students were still passive during the learning process. Although some students do not contribute to actively participate, they still pay attention. The teacher explained the materials about understanding a descriptive text, generic structure, and simple present tense. They also asked the teacher when they felt confused about certain things, like asking about simple present tense. Although students are still passive, the learning process continues to run well.

In the second meeting, some students participated more actively than at the first meeting. The researcher implemented the Bingo game. The material was about descriptive text (animal). Before starting Bingo game the teacher gave instruction students how to play Bingo game. The Bingo game is about the animal adjective. Most students interact more actively started from the beginning of the class especially when played bingo game. After they finished played Bingo game, the teacher discussed the meaning of the words. Students are divided into 6 groups and the teacher gave the students assignment to find adjectives to describe animals. Some students also asked about assignments such as:

A: Miss is green the color of frog?

When they don't know the vocabulary they looked up the dictionary or asked the teacher. In the second meeting, the students showed more confidence when they talked in front of their classmates. In the last meeting, all of the students participated actively during the lesson. The Bingo game is about people. They knew the rules of the technique, they immediately sat and work on Bingo sheet. After they finished playing Bingo game teacher discussed the meaning of the words in Bingo game. Then the teacher gave the assignment fill in blank space about Justin Bieber. In group they filled the task based on the teacher instruction they can finish the task, but some students still confused how to develop their idea.

From the observation sheet taken by the researcher, Bingo game was motivated students in the learning process. This is supported by theory from Febriansyah (2015) as cited in Akhyar (2017) that bingo games not only enhance vocabulary but can also motivate students, selfconfidence, and enthusiasm.

\section{CONCLUSION}

Bingo game was useful for the students in learning writing. From the data obtained by the interview, the students gave positive responses from all the questions related to learning writing using Bingo game. The students felt motivated and get a lot of new vocabularies and they thought that the learning process became interested and fun. 
Meanwhile, the data obtained from the observation sheet showed that the students involved in all aspects in observation sheet. The students became interested and enthusiastic in each meeting to learn writing using Bingo game. Bingo game made the students involved actively during the learning process.

Also, Bingo game can motivate students. It can be concluded that Bingo game is a good technique that can be used to motivate students in learning writing. Bingo game provides the students to learn writing more fun and active.

\section{ACKNOWLEDGMENTS}

First of all, thanks to Allah SWT, for his mercy and guidance in giving me full strength to complete this article. Thanks to my lecturer, Miss Evie Kareviati, M.Pd, for all of her support and guidance in helping me to finish this article.

\section{REFERENCES}

Akhyar, M. (2017). The Effectiveness of Bingo Games in Teaching Alaudin State Islamic University of Makassar.

Ernawati, R., Purnomo, N. F., \& Suryani, L. (2019). An Error Analysis in Writing Descriptive Text. PROJECT (Professional Journal of English Education), 2(5), 616-621.

Farizi, I., \& Fauzyah, F. (2019). The Use of Think Pair Share. 2(5), 752-756.

Hanafiawi, D., Muharam, H., \& Parmawati, A. (2020). The Use Of Clustering Technique to Improve Students'skill In Writing Descriptive Text. PROJECT (Professional Journal of English Education), 3(1), 5-10.

Jayanti, A. D. (2019). Students' Writing Ability on English Descriptive Text at Grade VIII in SMPN 33Padang. ENGLISH FRANCA (Academic Journal of English Language and Education), 3(1), 71-94.

Noviyanti, R., \& Bahri, S. (2019). The Use of Think Bingo Game to Improve Students' Vocabulary Mastery. Research in English and Education (READ), 4(February), 1-8.

Nurmalasari, M., \& Apsari, Y. (2019). Improving Students'participation in Speaking English Using Snowball Throwing Technique. Project (Professional Journal of English Education), 2(2), 115-121.

Yulianti, S., Nuraeni, S., \& Parmawati, A. (2019). Improving Students'writing Skill Using Brainswriting Strategy. Project (Professional Journal Of English Education), 2(5), 714721. 